\title{
Absence of Receptor Guanylyl Cyclase C Enhances Ileal Damage and Reduces Cytokine and Antimicrobial Peptide Production during Oral Salmonella enterica Serovar Typhimurium Infection
}

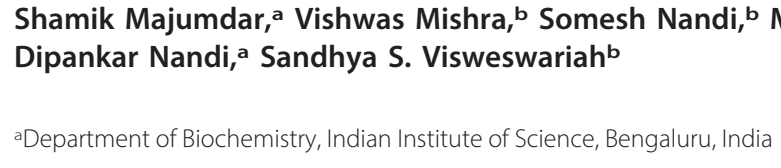 \\ bDepartment of Molecular Reproduction, Development and Genetics, Indian Institute of Science, Bengaluru, \\ India
}

ABSTRACT Nontyphoidal Salmonella disease contributes toward significant morbidity and mortality across the world. Host factors, including gamma interferon, tumor necrosis factor alpha, and gut microbiota, significantly influence the outcome of Salmonella pathogenesis. However, the entire repertoire of host protective mechanisms contributing to Salmonella pathogenicity is not completely appreciated. Here, we investigated the roles of receptor guanylyl cyclase C (GC-C), which is predominantly expressed in the intestine and regulates intestinal cell proliferation and fluid-ion homeostasis. Mice deficient in GC-C $\left(\right.$ Gucy $\left.2 \mathrm{C}^{-1-}\right)$ displayed accelerated mortality compared with that for wild-type mice following infection via the oral route, even though both groups possessed comparable systemic Salmonella infection burdens. Survival following intraperitoneal infection remained similar in both groups, indicating that GC-C offered protection via a gut-mediated response. The serum cortisol level was higher in Gucy $2 \mathrm{c}^{-/-}$mice than wild-type (Gucy $2 \mathrm{C}^{+/+}$) mice, and an increase in infection-induced thymic atrophy with a loss of immature $\mathrm{CD}^{+} \mathrm{CD}^{+}$ double-positive thymocytes was observed. Accelerated and enhanced damage in the ileum, including submucosal edema, epithelial cell damage, focal tufting, and distortion of the villus architecture, was seen in Gucy $2 \mathrm{c}^{-1-}$ mice concomitantly with a larger number of ileal tissue-associated bacteria. Transcription of key mediators of Salmonella-induced inflammation (interleukin-22/Reg3 $\beta$ ) was altered in Gucy2c-1mice in comparison to that in Gucy $2 \mathrm{C}^{+/+}$mice. A reduction in fecal lactobacilli, which are protective against Salmonella infection, was observed in Gucy2c ${ }^{-/-}$mice. Gucy $2 c^{-1-}$ mice cohoused with wild-type mice continued to show reduced amounts of lactobacilli and increased susceptibility to infection. Our study, therefore, suggests that the receptor GC-C confers a survival advantage during gut-mediated Salmonella enterica serovar Typhimurium pathogenesis, presumably by regulating Salmonella effector mechanisms and maintaining a beneficial microbiome.

KEYWORDS Salmonella enterica serovar Typhimurium, guanylyl cyclase C, guanylin, uroguanylin, thymic atrophy, goblet cell

almonellosis, the disease caused by the Gram-negative intracellular bacterium Salmonella, manifests in humans as typhoid, paratyphoid fever, nontyphoidal septicemia, or gastroenteritis. Infections with Salmonella enterica serotypes Typhi and Paratyphi are limited to humans, and these Salmonella serotypes cause the systemic disease typhoid fever. Infections with other serotypes, called nontyphoidal Salmonella serotypes, result in enteritis and diarrhea. Salmonella infects hosts orally via contami-
Received 6 November 2017 Returned for modification 3 December 2017 Accepted 9 February 2018

Accepted manuscript posted online 20 February 2018

Citation Majumdar S, Mishra V, Nandi S, Abdullah M, Barman A, Raghavan A, Nandi D, Visweswariah SS. 2018. Absence of receptor guanylyl cyclase $C$ enhances ileal damage and reduces cytokine and antimicrobial peptide production during oral Salmonella enterica serovar Typhimurium infection. Infect Immun 86:e00799-17. https://doi.org/10.1128/IA| .00799-17.

Editor Manuela Raffatellu, University of California San Diego School of Medicine Copyright $\odot 2018$ American Society for Microbiology. All Rights Reserved. Address correspondence to Sandhya S. Visweswariah, sandhya@iisc.ac.in.

S.M., V.M., and S.N. contributed equally to this article. 
nated food or water (1). Mouse infection models are useful to study not only factors in the pathogen that regulate disease progression but also host factors that can modulate the severity of the response to Salmonella infection (2). In susceptible mouse strains, such as those with defects in the gene encoding Slc11a1 (Nramp1), the bacterium traverses the distal ileum, and mice develop systemic infection after colonization of the Peyer's patches, liver, and spleen (3).

Colonization of the mouse intestine is dependent on a number of factors that include the commensal microbiota, the gut mucosa, and the gut-associated immune system. A number of host factors, such as gamma interferon (IFN- $\gamma$ ) (4), tumor necrosis factor alpha (TNF- $\alpha)(5,6)$, and interleukin-22 (IL-22), modulate Salmonella pathogenesis (1). These factors regulate the production of chemokines that recruit inflammatory cells to the site of tissue damage and infection (7). In addition, it is conceivable that modulators of intestinal epithelial cell function may also provide mechanisms to modulate Salmonella pathogenesis, since the first point of contact for the pathogen is the epithelial cells that line the gastrointestinal tract (8).

The receptor guanylyl cyclase C (GC-C) is a transmembrane receptor predominantly expressed on the apical membrane of intestinal enterocytes. It serves as a receptor for the endogenous hormones guanylin and uroguanylin $(9,10)$. Activation of GC-C upon ligand binding results in production of CGMP, which leads to protein kinase G IIdependent activation of the cystic fibrosis transmembrane conductance regulator (CFTR) and inhibition of sodium-hydrogen exchanger 3 (NHE3). Activation of CFTR causes the efflux of chloride, CFTR-dependent bicarbonate secretion into the lumen, and inhibition of sodium absorption by NHE3, thus resulting in an osmotic gradient leading to fluid accumulation in the lumen. Hence, the major role of GC-C is in maintenance of fluid-ion homeostasis in the gut (11). In addition, GC-C serves as the receptor for the heat-stable enterotoxin (ST), the causative agent of enterotoxigenic Escherichia coli (ETEC)-mediated diarrhea in children and traveler's diarrhea (12). Mice lacking GC-C are resistant to heat-stable enterotoxin-induced fluid accumulation (13) and are reported to display greater susceptibility to dextran sodium sulfate-induced colitis (14). Previously, we have demonstrated that mice lacking GC-C show increased $\mathrm{N}$-methyl- $\mathrm{N}$-nitrosourea-induced aberrant crypt foci (15), indicating a role for GC-C in maintaining intestinal cell proliferation.

Gucy $2 c^{-1-}$ mice have been reported to possess a compromised gut epithelial barrier which was attributed to the lower expression of tight junction proteins, such as occludin, claudin 2, and claudin 4 (14). Citrobacter rodentium, an enteric Gram-negative bacterium, causes self-limiting infection in mice, and Gucy $2 \mathrm{c}^{-1-}$ mice are reported to be more susceptible to infection by that bacterium (16). Here, we studied the role of GC-C as a host factor during Salmonella-mediated pathogenesis in mice. We found that, in contrast to expectations that a compromised gut barrier would lead to enhanced systemic infection, the increased susceptibility of Gucy $2 c^{-1-}$ mice to oral infection with Salmonella Typhimurium was a result of an increased bacterial load in the ileum, altered cytokine production, and increased ileal tissue damage coupled to an altered fecal microbiome.

\section{RESULTS}

Mice lacking GC-C display accelerated mortality during oral S. Typhimurium

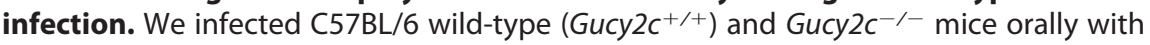
$S$. Typhimurium and monitored their survival. We chose not to treat the mice with streptomycin (17), since we were interested in a model of acute S. Typhimurium infection without altering the existing microbiota in these mice (18). Surprisingly, survival experiments revealed an increased susceptibility of Gucy2c $c^{-1-}$ mice to oral but not intraperitoneal infection with S. Typhimurium (Fig. 1a), indicating a role for GC-C in offering protection against gut-associated infection. The median length of survival for Gucy $2 c^{+/+}$mice following oral infection was $112 \mathrm{~h}$, while it was $80 \mathrm{~h}$ for Gucy $2 \mathrm{c}^{-/-}$ mice, and the difference was statistically significant $(P=0.006)$. Interestingly, fecal excretion of bacteria was similar in Gucy $2 c^{+/+}$and Gucy $2 c^{-1-}$ mice at early stages of 
a
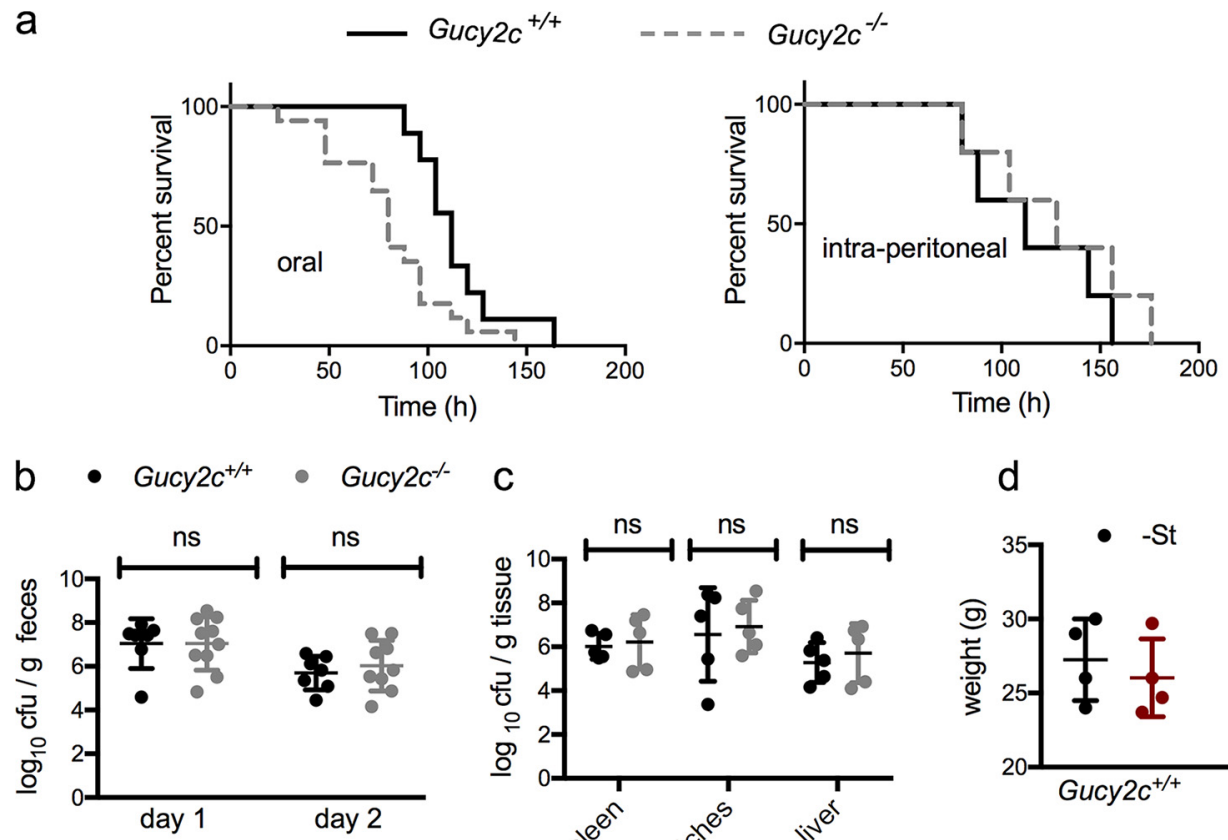

C
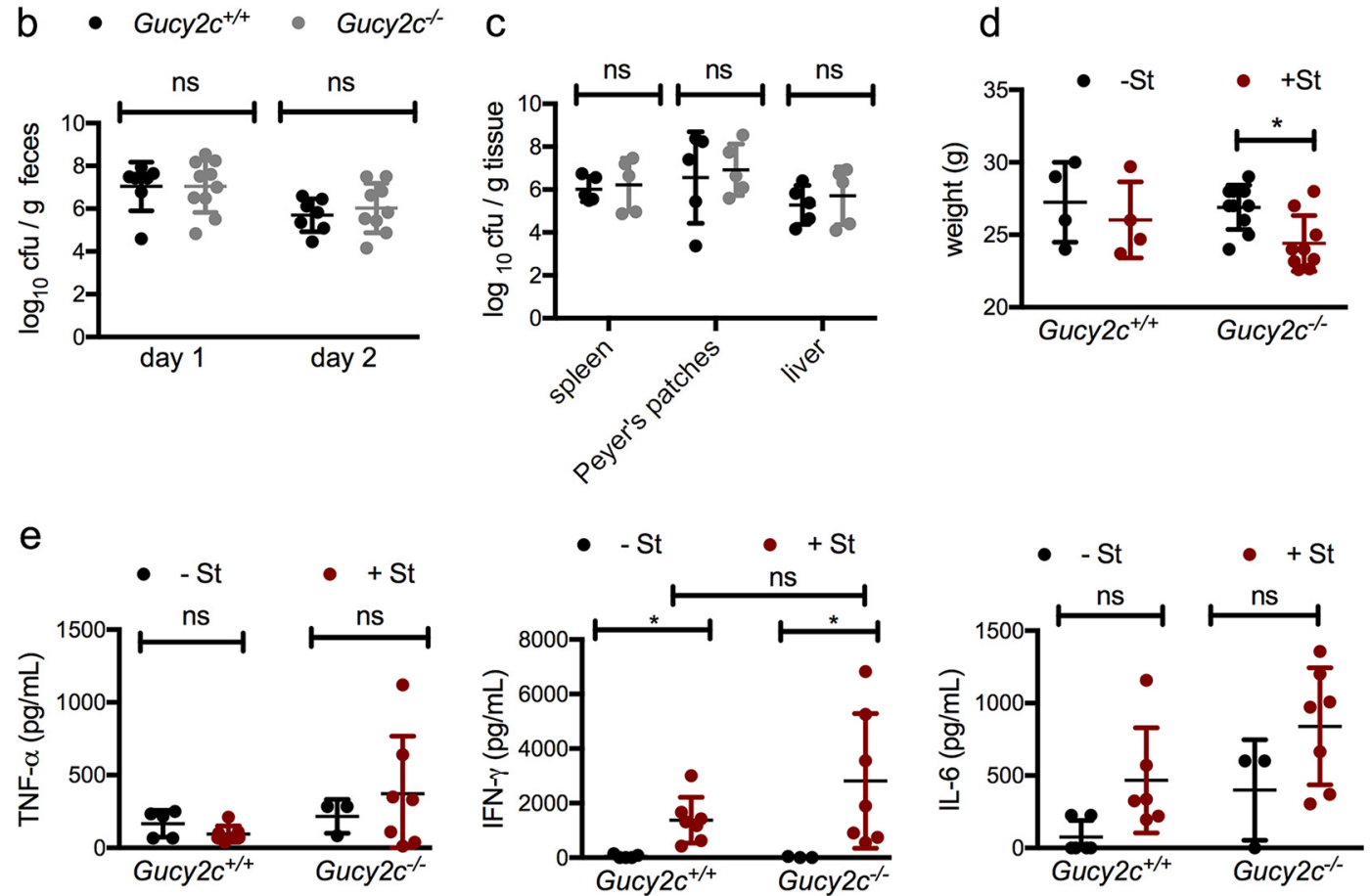

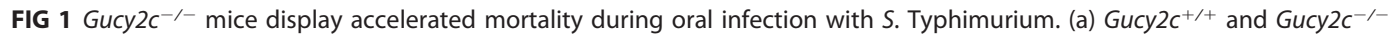
mice were infected with $S$. Typhimurium either orally or intraperitoneally. The mice were monitored for survival at 8 -h intervals. Survival curves for oral and intraperitoneal infection were obtained from independent experiments containing a total of 10 to 11 mice. (b) Mice were orally infected with S. Typhimurium, and the bacterial loads in the feces on days 1 and 2 following infection were estimated. The data show the values for individual mice, with error bars showing the mean \pm SD. (c) Infected mice were sacrificed on day 3, tissues were harvested, and the bacterial burden in the spleen, Peyer's patches, and liver was estimated. Data show the values for individual mice, with error bars showing the mean \pm SD. (d) Mice were weighed prior to oral infection and at 3 days postinfection. (e) Sera were collected from uninfected and infected mice, and the levels of TNF- $\alpha$, IFN- $\gamma$, and IL- 6 were measured by ELISA. In panels $b$ to e, the data are depicted as the mean \pm SD for 3 to 7 mice per group. The statistical significance of the differences among the experimental groups in all panels was analyzed using two-way ANOVA. ${ }^{*}, P \leq 0.05$; ns, not significant; $-\mathrm{St}$, mice not infected with $S$. Typhimurium; $+\mathrm{St}$, mice infected with $S$. Typhimurium.

infection, as was the bacterial burden in organs, such as the spleen, Peyer's patches, and liver, on day 3 postinfection (Fig. $1 \mathrm{~b}$ and C). In agreement with earlier observations (19), poor survival after Salmonella infection was correlated with a significant reduction

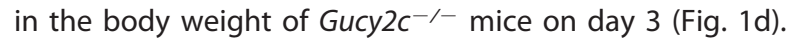

Next, we monitored proinflammatory cytokine levels in serum 3 days after oral infection, to determine whether enhanced immune cell activation and inflammation were responsible for the poor survival of Gucy2 $\mathrm{c}^{-1-}$ mice. As shown in Fig. 1e, while there was a tendency for an increase in serum TNF- $\alpha$ and IL- 6 levels on infection, the increase was not statistically significant. IFN- $\gamma$ levels were elevated on infection in both

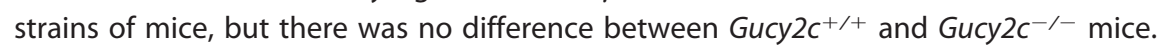
Therefore, we conclude that an increase in systemic infection or inflammation was not

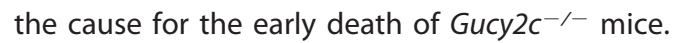




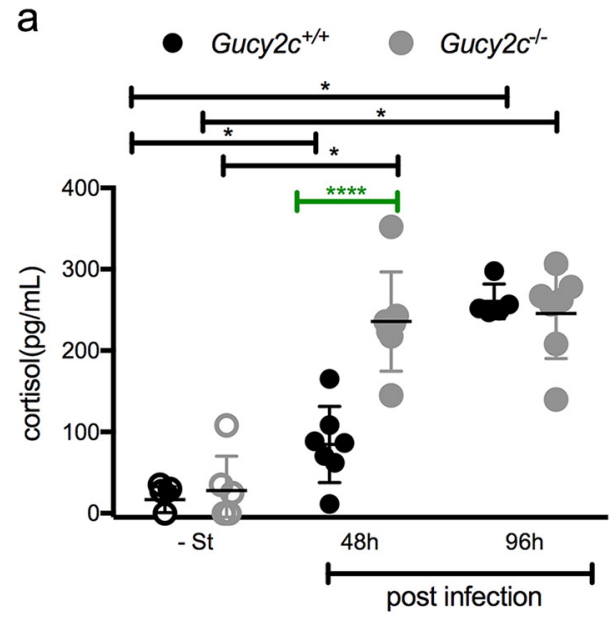

C

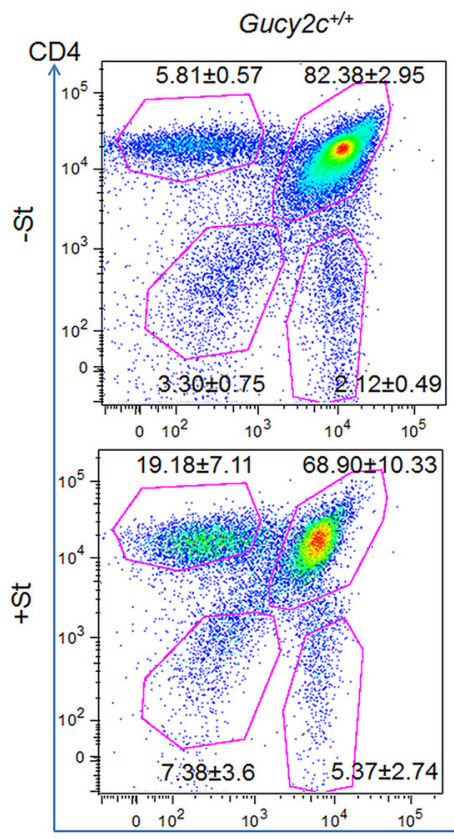

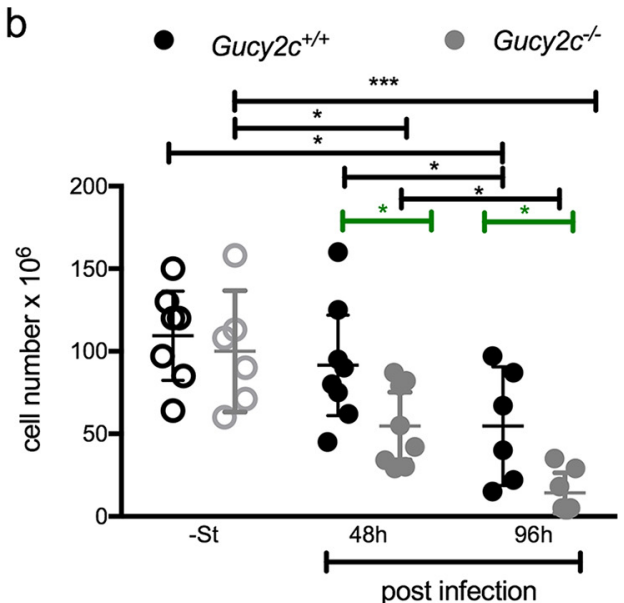

Gucy2c-
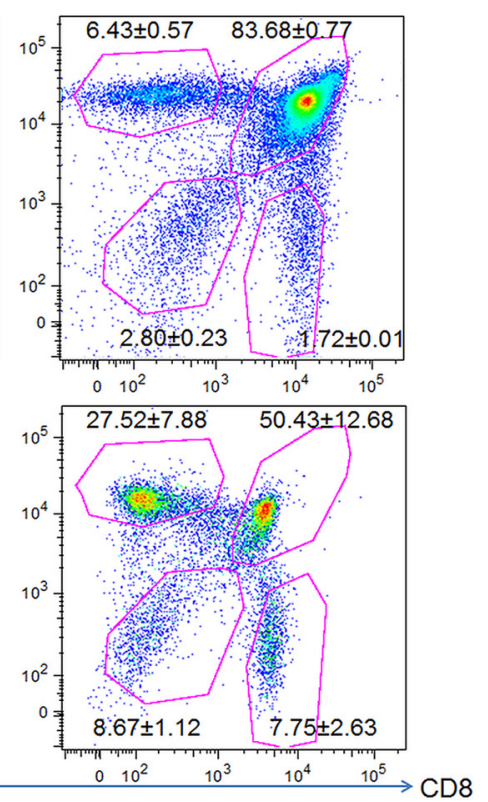

FIG 2 An early rise in serum cortisol amounts and increased infection-induced thymic atrophy are observed in Gucy $2 c^{-1-}$ mice. (a) Gucy $2 c^{+/+}$and Gucy $2 c^{-1-}$ mice were orally infected with S. Typhimurium. At the indicated time points, $S$. Typhimurium-uninfected $(-S t)$ and $S$. Typhimurium-infected $(+S t)$ mice were sacrificed and serum cortisol levels were measured by ELISA. Data show the values for individual mice, with error bars showing the mean \pm SD. (b) Viable cells from harvested thymi were quantified by trypan blue exclusion assay using a hemocytometer. (c) The thymocytes from uninfected mice and from mice after $96 \mathrm{~h}$ of infection were stained for cell surface expression of CD4 and CD8, and density plots were constructed to quantify the percentages of the major cell populations. Data are depicted as the mean \pm SEM for 5 to 8 mice per group. In all panels, experimental groups were analyzed for statistical significance using two-way ANOVA, ${ }^{*}, P \leq 0.05 ;{ }^{* * *}, P \leq 0.001 ;{ }^{* * * *}, P \leq 0.0001$. Green bars indicate differences between Gucy $2 \mathrm{C}^{+/+}$and Gucy $2 \mathrm{c}^{-1-}$ mice that were statistically significant.

Enhanced infection-induced thymic atrophy is observed in Gucy2c ${ }^{-1-}$ mice. We have previously reported that serum cortisol, a marker of the general stress experienced by the animal, is increased on Salmonella infection and contributes toward $S$. Typhimurium-induced thymic atrophy in mice $(20,21)$. We monitored cortisol levels and observed an increase in serum cortisol levels on infection. However, at $48 \mathrm{~h}$, Gucy $2 c^{-1-}$ mice showed higher levels of circulating cortisol than Gucy $2 c^{+/+}$mice (Fig. 2a). Thymic atrophy was observed in both Gucy $2 \mathrm{c}^{+/+}$and Gucy $2 \mathrm{c}^{-/-}$mice (Fig. 2b and c) but was more pronounced in Gucy2c ${ }^{-/-}$mice at both 48 and $96 \mathrm{~h}$ postinfection (Fig. 2b). CD4 and CD8 cell surface staining of isolated thymocytes revealed an increased depletion of $\mathrm{CD}^{+} \mathrm{CD}^{+}$thymocytes in Gucy2 $\mathrm{c}^{-1-}$ mice after $96 \mathrm{~h}$ of infection (Fig. 2c). 

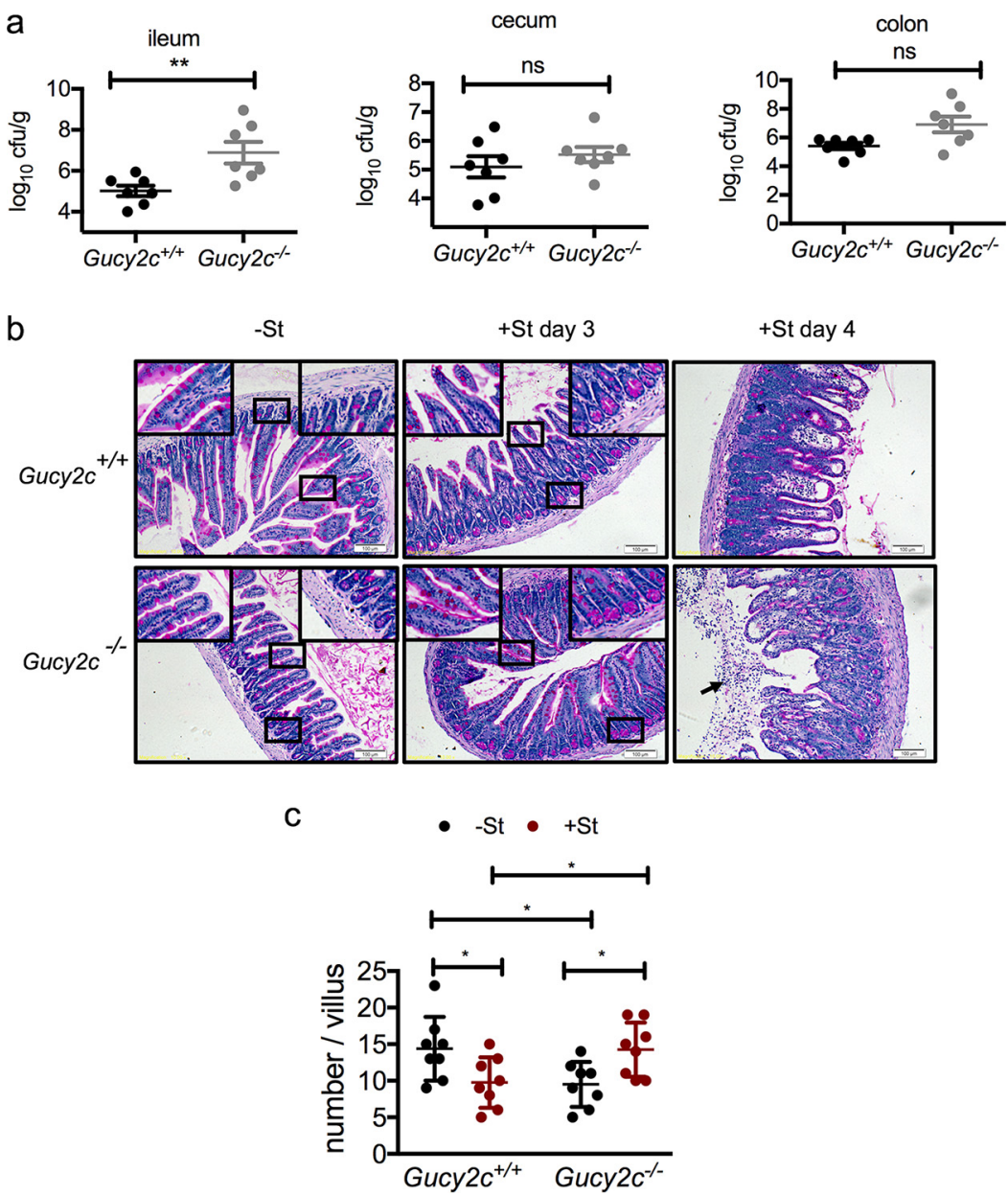

FIG 3 Gucy $2 c^{-1-}$ mice show increased bacterial colonization and intestinal damage. Infected Gucy $2 c^{+/+}$ and Gucy $2 c^{-1-}$ mice were sacrificed at 3 days after oral S. Typhimurium infection. (a) The bacterial load in the ileum, cecum, and colon was estimated. Each circle represents the value for an individual mouse, and lines show the mean \pm SD. ${ }^{* *}, P<0.01$; ns, not significant. (b) Periodic acid-Schiff (PAS) staining was performed on formalin-fixed ileal tissue sections obtained from $S$. Typhimurium-uninfected ( $-\mathrm{St}$ ) and $S$. Typhimurium-infected ( + St) mice on days 3 and 4 following infection. One representative ileal tissue section from each experimental group containing 3 to 4 mice is depicted. Bars, $100 \mu \mathrm{m}$. The arrow shows a large number of apoptotic cells in the lumen of Gucy $2 c^{-1-}$ mice. (Insets) The larger boxes are enlarged images of the smaller boxes. (c) The number of goblet cells was quantified in individual, clearly identifiable villi in each section from uninfected and infected mice. The data shown are from an individual villus across a section, and lines indicate the mean \pm SD. Statistical analysis was performed by two-way ANOVA. *,$P \leq 0.05$.

Increased epithelial damage in the small intestine is observed in Gucy2c-/mice. Results so far suggest that the protective effects of GC-C are mediated predominantly at the level of the gastrointestinal tract and could be initiated early during infection, thereby resulting in significant weight loss and earlier death in Gucy2c-1mice. We therefore monitored the bacterial load in various regions of the gut following infection in both Gucy $2 c^{+/+}$and Gucy $2 c^{-/-}$mice. The CFU were enumerated on day 3 following infection, at which time a few Gucy $2 c^{-/-}$mice had already succumbed. As shown in Fig. 3a, while the bacterial loads in the cecum and colon were similar in both strains of mice, the increase in the amount bacteria seen in the distal ileum was on the order of almost 2 logs.

We measured ileal damage and goblet cell number on day 3, using periodic acid-Schiff (PAS) staining following paraformaldehyde fixation. Examination of sections of the small intestine showed marked histopathological differences between infected Gucy $2 c^{+/+}$and Gucy $2 c^{-/-}$mice. Infection resulted in more severe inflammation in the 
small intestine of Gucy2c-/- mice, with increased focal tufting and distortion of the crypt villus architecture by day 4 (Fig. 3b). A larger number of dead cells was also observed in the lumen of the ileum in Gucy2 $\mathrm{C}^{-1-}$ mice than in the lumen of the ileum in Gucy $2 \mathrm{C}^{+/+}$mice by day 4 postinfection.

PAS staining revealed a reduced number of goblet cells in uninfected Gucy $2 c^{-1-}$ mice (Fig. 3c). Goblet cell numbers were reduced in Gucy $2 c^{+/+}$mice on infection, as has been reported earlier (17), but were increased in Gucy2c-/- mice. Also noteworthy was the intense staining of Paneth cells in the crypts of both Gucy $2 c^{+/+}$and Gucy2c $\mathrm{c}^{-/-}$ mice following infection.

S. Typhimurium infection downregulates the transcription of GC-C and its ligands, guanylin and uroguanylin. Results so far indicate that signaling via GC-C protects the host during Salmonella infection by reducing the extent of tissue damage and colonization in the ileum. We therefore asked if infection alters the expression of genes in the GC-C signaling pathway, which could be a strategy used by Salmonella to increase its virulence in the host. We performed quantitative real-time PCR analysis of cDNA prepared from the distal ileum of mice on day 3 following oral infection and observed that the transcript levels of GC-C were significantly reduced on infection in Gucy $2 c^{+1+}$ mice (Fig. 4). The distal ileum may be a region where both guanylin and uroguanylin are expressed to comparable levels (22), and interestingly, the transcript levels of both the ligands were reduced on infection in both Gucy $2 \mathrm{C}^{+/+}$and Gucy $2 \mathrm{c}^{-/-}$ mice (Fig. 4). Other genes downstream of GC-C did not show a change in expression levels (Cftr, Pkgll, and Pde5) on infection, while Nhe3 transcripts were upregulated in both infected Gucy2 $\mathrm{C}^{+/+}$mice and infected Gucy $2 \mathrm{c}^{-/-}$mice. Activation of GC-C results in cGMP-dependent phosphorylation of NHE3, which inhibits this $\mathrm{Na}^{+} / \mathrm{H}^{+}$exchanger $(11,23)$. Therefore, the downregulation of guanylin and uroguanylin transcripts, coupled with the increased expression of $\mathrm{Nhe3}$, would enhance $\mathrm{Na}^{+}$uptake by the epithelial cells, possibly counteracting the loss of this ion during Salmonella-induced diarrhea in humans.

GC-C regulates transcription of cytokines and effectors during Salmonella infection. Intestinal inflammation following Salmonella infection is a consequence of upregulation of proinflammatory genes, including Tnf- $\alpha, I 1-1 \beta, \| 1-22, I I-6$, and Ifn- $\gamma$ (24), and genes expressing the C-type lectins $\operatorname{Reg} 3 \gamma$ and $\operatorname{Reg} 3 \beta$ (1). The transcripts of most cytokines were upregulated to similar extents in both Gucy $2 \mathrm{C}^{+/+}$and Gucy $2 \mathrm{c}^{-/-}$mice following infection (Fig. 5). The transcript levels of only a few genes (II-22, CxCl15, and Reg3 $\beta$; see the green bars in Fig. 5) differed statistically between Gucy $2 c^{+/+}$and Gucy $2 c^{-1-}$ mice following infection. While lipocalin 2 gene transcript levels were significantly increased in Gucy $2 c^{-1-}$ mice, there was no statistically significant difference between the levels in wild-type and Gucy $2 \mathrm{C}^{-1-}$ mice following infection. In summary, this indicates a role for GC-C signaling in modulating specific arms of the Salmonella-induced immune response.

Reduced levels of lactobacilli in Gucy2c $c^{-/-}$mice may contribute to the initial susceptibility of mice to Salmonella infection. The gut microbiota is known to influence Salmonella infection progression $(17,18,25,26)$. We therefore monitored the major phyla of bacteria present in the mouse gut and also Lactobacillus spp., which have been reported to protect from Salmonella infection (25-28). We prepared genomic DNA from stool samples from both Gucy $2 \mathrm{c}^{+/+}$and Gucy $2 \mathrm{c}^{-/-}$mice and performed real-time PCR using universal and phylum-specific primers for the 16S rRNA genes. As shown in Fig. 6, while the major phyla (Bacteriodetes and Firmicutes) were largely unchanged in both strains of mice, Lactobacillus spp. were significantly reduced. Since lactobacilli have been reported to attenuate the severity of salmonellosis in mice (25), we propose that the initial environment of the gut of Gucy2c $c^{-1-}$ mice could also have contributed to the initial infection and uptake of $S$. Typhimurium, culminating in the increased susceptibility of Gucy $2 c^{-1-}$ mice to infection.

To ensure that alterations in the microbiome in Gucy $2 \mathrm{c}^{-/-}$mice were a direct consequence of the absence of GC-C in the gut, we cohoused Gucy $2 c^{-/-}$mice at the time of weaning with adult wild-type mice for 4 weeks. We then monitored the feces 

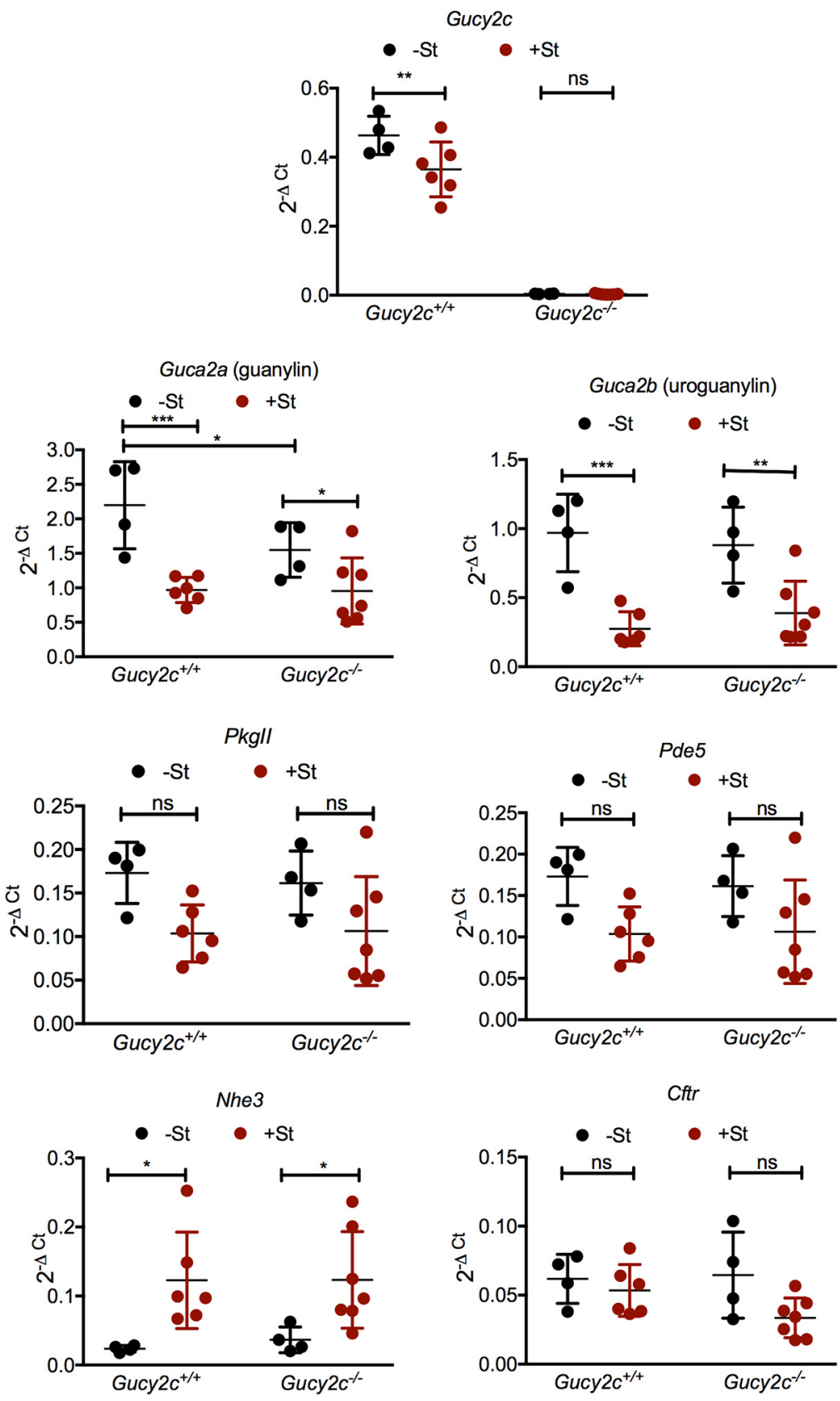

FIG 4 S. Typhimurium infection regulates the expression of genes in the GC-C signaling pathway. RNA was prepared from ileal tissue of $S$. Typhimurium-uninfected $(-\mathrm{St})$ and $S$. Typhimurium-infected $(+\mathrm{St})$ mice on day 3 following oral infection. Quantitative real-time PCR analysis was performed to estimate the transcript levels of Gucy2c, Guca2a, Guca2b, Pkgll, Pde5, Nhe3, and Cftr. The data are depicted as values for individual mice, and lines represent the mean \pm SD. Two-way ANOVA was used to analyze the results for statistically significant differences among the experimental groups. ${ }^{*}, P \leq 0.05 ;{ }^{* *}, P \leq 0.01 ;{ }^{* * *}, P \leq$ $0.001 ; \mathrm{ns}$, not significant.

collected from cohoused mice for major phyla. We continued to observe a similar composition of microbiota after cohousing, including lower levels of lactobacilli in

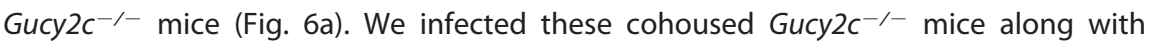
age-matched wild-type mice, housed both strains of mice together in multiple cages following infection, and monitored survival. In agreement with earlier results, we saw

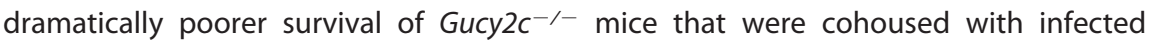
Gucy $2 \mathrm{C}^{+/+}$mice following infection (Fig. 6b). Similar fecal bacterial loads (Fig. 6c) were observed in all mice, but Gucy $2 \mathrm{c}^{-1-}$ mice showed a marked reduction in body weight 

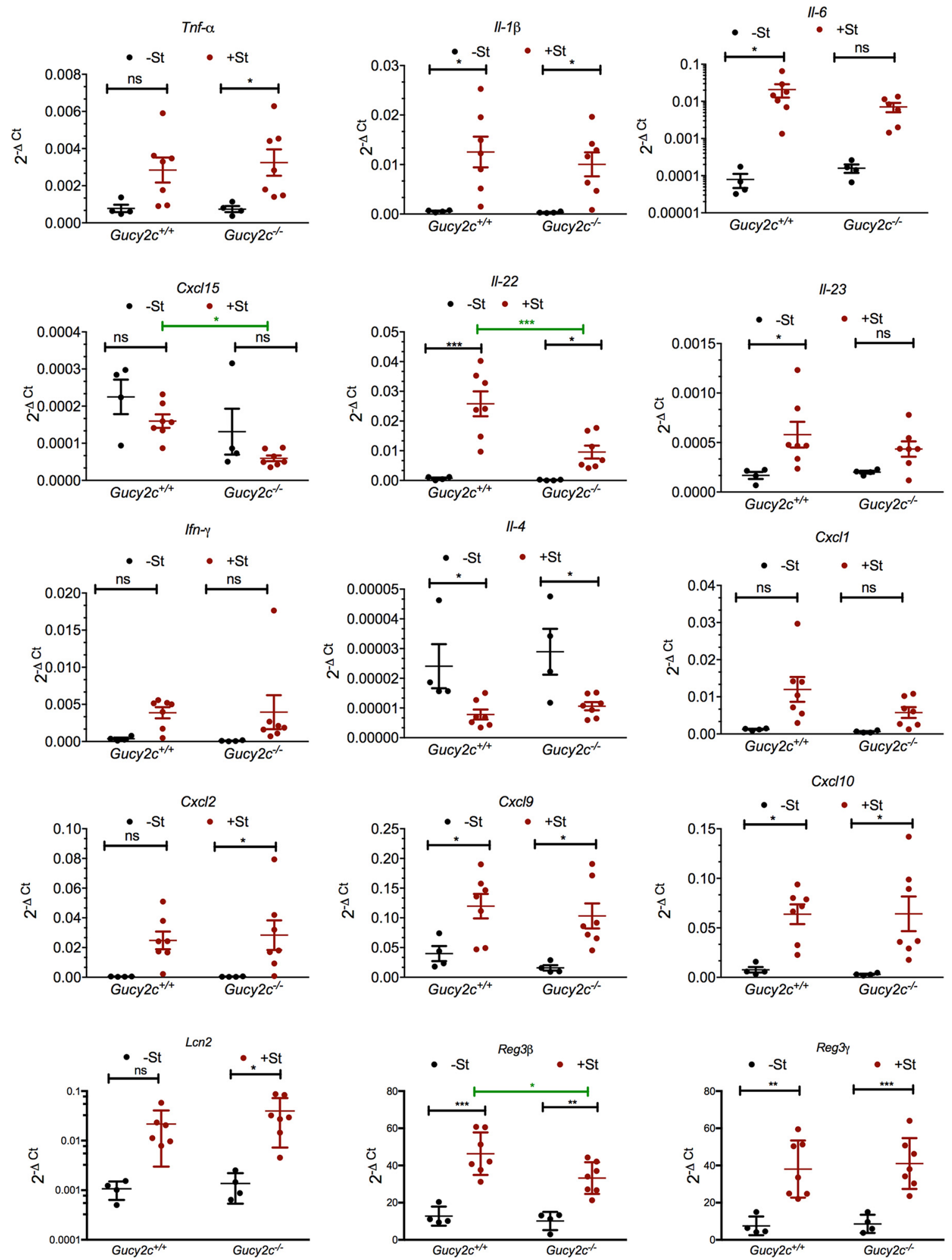

FIG 5 Gucy $2 c^{-1-}$ mice show reduced transcript levels of IL-22 in the ileum following infection. Gucy $2 c^{+/+}$and Gucy $2 c^{-/-}$mice orally infected with S. Typhimurium (+St) along with control S. Typhimurium-uninfected mice ( - St) were sacrificed at 3 days postinfection. RNA was isolated from the harvested ileal tissues, and quantitative real-time PCR analysis was performed to estimate the transcript levels of

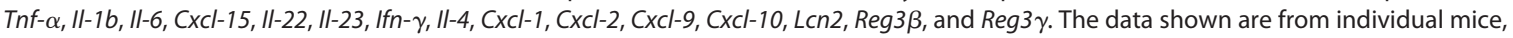
and lines depict the mean \pm SD. The differences between the experimental groups were analyzed for statistical significance using two-way ANOVA. ${ }^{*}, P \leq 0.05 ;{ }^{* *}, P \leq 0.01 ;{ }^{* *}, P \leq 0.001 ;$ ns, not significant. Green bars represent values which differed significantly between Gucy $2 \mathrm{C}^{+/+}$and Gucy $2 \mathrm{c}^{-1-}$ mice. 

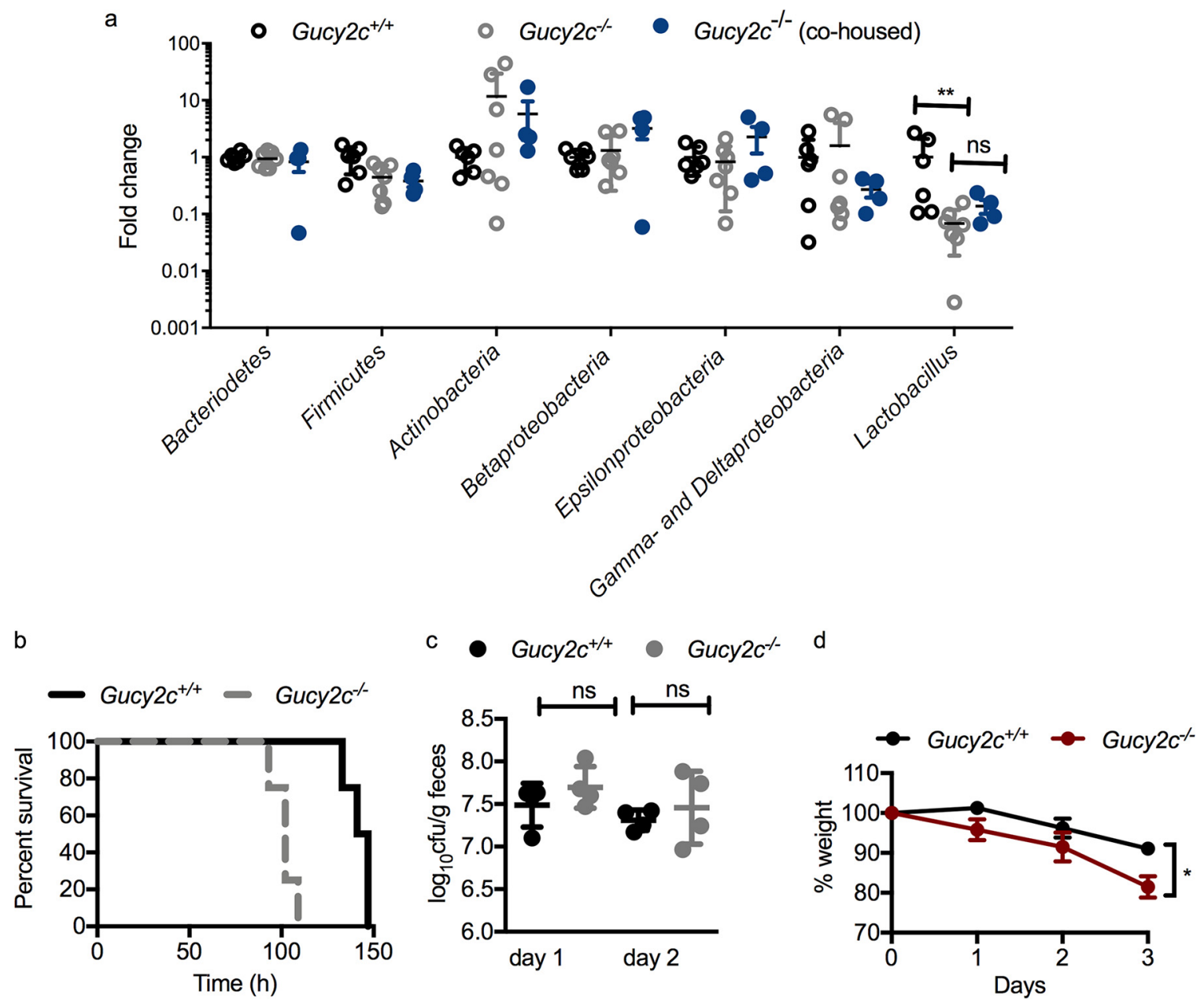

FIG 6 Abundance of major microbial phyla and infection outcome are not altered in cohoused Gucy $2 c^{-1-}$ and Gucy $2 c^{+/+}$mice. (a) Fecal pellets were collected from uninfected Gucy $2 c^{+/+}$and Gucy $2 c^{-1-}$ mice and Gucy $2 c^{-1-}$ mice cohoused with wild-type mice, and the bacterial DNA was isolated from the samples. Quantitative real-time PCR was performed to analyze the levels of gut microbiota using phylum-specific primers normalized to universal $16 \mathrm{~S}$ rRNA-specific primers. The values shown represent those for individual mice, and lines show the mean \pm SD. Statistical analysis was performed using the nonparametric Mann-Whitney $U$ test. ${ }^{* *}, P \leq 0.01 ;$ ns, not significant. (b) Gucy $2 c^{+/+}$mice and cohoused Gucy $2 c^{-/-}$mice (4 mice of each species) were infected with $S$. Typhimurium and housed together in multiple cages during the course of infection. The survival of the mice was monitored every $8 \mathrm{~h}$. (c) Fecal pellets from individual mice were collected at $24 \mathrm{~h}$ and $48 \mathrm{~h}$ following infection of mice, and the bacterial loads in the feces on days 1 and 2 following infection were estimated. Data show the values for individual mice, with error bars showing the mean \pm SD. (d) Individual mice were weighed prior to infection and then every day following infection until day 3 (when Gucy $2 c^{-1-}$ mice had started to succumb to infection). The data shown are the mean $\pm \mathrm{SD}(n=4) .{ }^{*}, P<0.05$.

by day 3 (Fig. $6 \mathrm{~d}$ ). Therefore, these cohousing experiments suggested that the susceptibility of Gucy $2 c^{-1-}$ mice to Salmonella infection is caused by genetically determined changes in the gut response and microbiome composition.

\section{DISCUSSION}

GC-C-mediated cGMP pathways are essential regulators of intestinal homeostasis, including fluid-ion secretion and cell proliferation (23). The role of GC-C in diarrhea caused by enterotoxigenic $E$. coli, which produces heat-stable enterotoxins, is well established, since GC-C serves as the receptor for the toxin (11). However, the roles of GC-C, if any, during severe enteric infections have not been investigated. Here, we utilized the $S$. Typhimurium infection model in mice, which results in an acute, progressive, and lethal infection, to study the contribution of GC-C during Salmonella pathogenesis. Our results show that GC-C provides protection against oral S. Typhimurium infection, and the absence of GC-C was correlated with reduced ileal damage and changes in the levels of some cytokines and antimicrobial peptides (AMPs) $(1,24)$ 


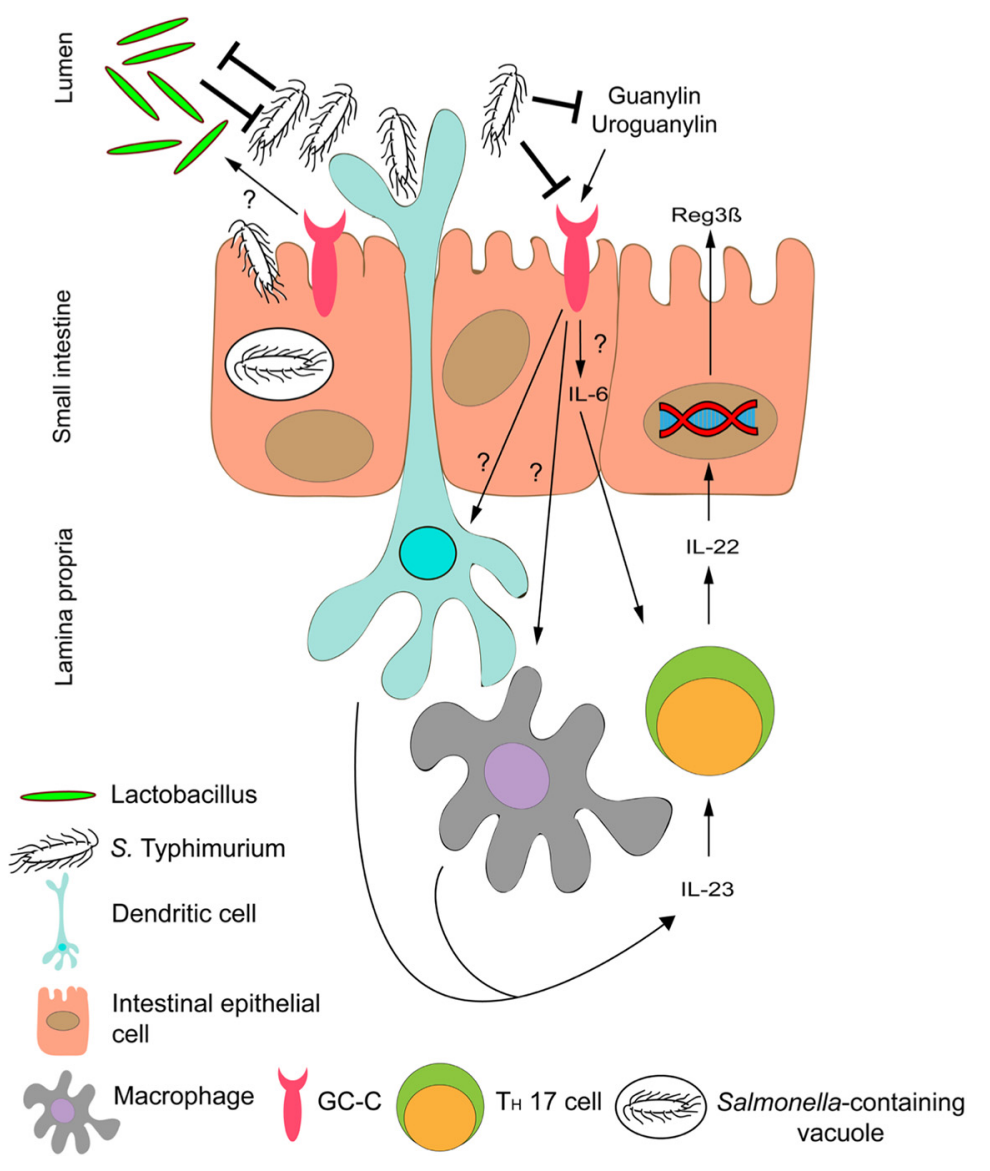

FIG 7 Putative role of GC-C during Salmonella infection. The IL-22 arm of the innate immune response during Salmonella infection is regulated by GC-C. After oral infection in mice, Salmonella competes with the commensal Lactobacillus bacteria to invade the epithelial and dendritic cells of the gut. Salmonella downregulates the expression of the GC-C receptor and its endogenous ligands, guanylin and uroguanylin. The probable interaction of GC-C with dendritic cells and macrophages leads to induction of IL-23 expression, which activates $T_{H} 17$ cells to express the cytokine IL-22, which in turn induces the expression of the AMP Reg3 $\beta$ in epithelial cells.

(Fig. 7). Interestingly, the rapid mortality seen in Gucy2c-/- mice was not dependent on increased systemic infection, since bacteria colonized extraintestinal tissue to equiva-

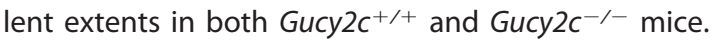

Glucocorticoids (GCs) are steroid hormones which are secreted by the adrenal glands and possess immunosuppressive properties. GCs are an indicator of stress (29) and are upregulated during S. Typhimurium infection in mice (21). At $48 \mathrm{~h}$ postinfection, the serum cortisol levels seen in Gucy $2 c^{-1-}$ mice were significantly higher than those seen in Gucy2 $\mathrm{c}^{+/+}$mice. Thymic atrophy accompanies numerous infections, and GCs contribute toward the depletion of the developing $\mathrm{CD}^{+} \mathrm{CD}^{+}$immature thymocytes during infections by pathogens, such as Listeria monocytogenes, type A Francisella tularensis, Trypanosoma cruzi, and S. Typhimurium $(20,21)$. Since Gucy $2 c^{-1-}$ mice displayed early elevated levels of serum cortisol (Fig. 2a), the infection-induced thymic atrophy in Gucy $2 c^{-1-}$ mice was indeed observed to be significantly higher than that in Gucy2c ${ }^{+/+}$mice.

Higher circulating cortisol levels could be attributed to enhanced colonization and inflammation in Gucy $2 c^{-1-}$ mice, as evidenced by the histopathology of the ileum. S. Typhimurium infection results in inflammation of the cecum and colon, with lower levels of inflammation being seen in the ileum of mice (30). Germfree mice display higher ileal loads than specific-pathogen-free mice when administered with similar doses of S. Typhimurium (31). The higher levels of colonization in the ileum of 
Gucy $2 c^{-1-}$ mice may be due to the higher level of translocation or invasion of Salmonella in the gut of these mice. Interestingly, during Crohn's disease, selective inflammation in the terminal ileum is observed (32). In addition, the standard therapy for inflammatory bowel disease (IBD) is administration of corticosteroids, which facilitate immunosuppression (33). The elevated levels of cortisol observed in Gucy2c-1mice during infection (Fig. 2a) might be a compensatory mechanism to reduce the inflammation of the ileum.

Salmonella pathogenesis results in an altered gene expression profile in the intestine (1). The transcript levels of GC-C and its endogenous ligands, guanylin and uroguanylin, were downregulated upon infection in the ileum (Fig. 4). However, the transcript levels of other downstream effectors of the GC-C pathway, such as Pkgll, Cftr, and Pde5, were not differentially modulated postinfection. NHE3 is an abundantly expressed $\mathrm{Na}^{+} / \mathrm{H}^{+}$ exchanger in the intestine $(11,34)$. There was a significant increase in the level of expression of NHE3 upon infection, which occurred independently of the presence of GC-C. The significant increase in NHE3 transcript levels is counterintuitive, since there are reports of downregulation of NHE3 by proinflammatory cytokines, such as IFN- $\gamma$ and TNF- $\alpha$, during enteropathogenic $E$. coli infection and inflammatory bowel disease (34). The mechanisms that lead to transcriptional regulation of NHE3 upon Salmonella infection are unknown and warrant further investigation.

There are only two reports of disruption of GC-C signaling at both the receptor and ligand levels, as we saw here on Salmonella infection (Fig. 4). In ulcerative colitis patients, a severity-dependent downregulation in the expression of GC-C, guanylin, and uroguanylin in the colonic mucosa is observed (35). GC-C and its ligands are also downregulated in the inflamed colonic mucosa of IBD patients (36) and in rats with 2,4,6-trinitrobenzene sulfonic acid-induced colitis (37). The significant downregulation of GC-C and its ligands upon Salmonella infection could therefore occur as a consequence of the altered composition of the tissue following the inflammation induced by infection.

Salmonella infection and invasion of the intestine induce inflammatory responses, including upregulation of proinflammatory cytokines (24). The induction of TNF- $\alpha$ in the gastrointestinal tract during Salmonella infection is well-known $(5,6)$. Small amounts of TNF- $\alpha$ confer protection against Salmonella infection in mice (38), while administration of higher doses causes extensive histopathological damage, organ dysfunction, and death within minutes to hours due to respiratory arrest $(39,40)$. Following infection, there was no statistically significant difference between the transcript levels of TNF- $\alpha$ in the ileum of wild-type mice and those in the ileum of Gucy $2 c^{-1-}$ mice (Fig. 5). TNF- $\alpha$ mediates the depletion of goblet cells during $S$. Typhimurium infection in mice, as pretreatment with anti-TNF- $\alpha$ antibody restores the goblet cell numbers and mucin profiles (6). We, however, saw an increase in goblet cell numbers on infection in the small intestine in Gucy2 $c^{-1-}$ mice (Fig. 3c), suggesting a novel means of regulating goblet cell number by GC-C.

A critical arm of the antimicrobial innate immune response is the production of epithelial cell-derived AMPs. This antimicrobial response is mediated via the IL-22 cytokine, which induces the expression of AMPs in the intestinal epithelial cells (1). IL-22 is produced by leukocytes, such as T helper type $17\left(T_{H} 17\right)$ cells, in response to the IL-23 produced by infected dendritic cells and macrophages (41) and/or the IL-6 produced by intestinal epithelial cells (42). AMPs induced by IL-22 include REG3 $\beta$, REG3 $\gamma$, lipocalin 2, and calprotectin. REG3 $\beta$ and REG3 $\gamma$ are bactericidal C-type lectins and eliminate Gram-positive bacteria $(1,43)$. Lipocalin 2 and calprotectin do not kill bacteria directly but starve them of metals which are essential for their growth (1). This AMP response has been demonstrated to impart a growth advantage to Gram-negative pathogens, such as Salmonella, over commensal bacteria (44). Reg $3 \gamma^{-1-}$ and $\operatorname{Reg} 3 \beta^{-1-}$ mice are more susceptible to Salmonella Enteritidis infection, implying a protective role of these AMPs against this pathogen $(45,46)$. The lower infection-induced expression of IL-22 in Gucy $2 c^{-1-}$ mice (Fig. 5) may affect the induction of AMPs in the epithelial cells, and indeed, the transcript levels of Reg $3 \beta$ were found to be significantly lower upon 


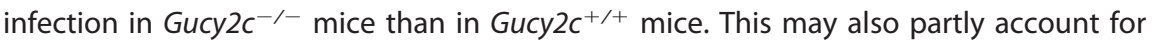
the susceptibility of these mice to Salmonella infection.

Innate lymphoid cells are potent producers of IL-22 after intestinal injury. Importantly, IL-22 has been shown to induce intestinal epithelial regeneration by increasing the proliferation of intestinal stem cells (47). Gucy $2 c^{-1-}$ mice showed a reduction in II-22 transcript levels on infection (Fig. 5). It is possible that the increased intestinal damage seen in Gucy2c-1- mice could be a consequence of the reduced proliferation of stem cells and, therefore, replenishment of epithelial cells.

The gastrointestinal tract is a rich source of aryl hydrocarbon receptor (AhR) ligands (48). AhR protects the gut upon challenge with pathogenic bacteria (49) by increasing IL-22 expression. Thus, AhR-deficient mice succumb to Citrobacter rodentium infection, and ectopic expression of IL-22 protected mice from this early mortality (49). It would therefore be of interest to monitor AhR expression in the gut of Gucy $2 c^{-/-}$mice and determine whether this contributes to reduced II-22 transcript levels in infected mice.

The gut microbiota is a critical determinant of susceptibility to various infectious pathogens (50), including S. Typhimurium $(17,18,25,26)$. The gut microbiota can either promote resistance to colonization by pathogens or assist and enhance their virulence (50). In our study, there were no significant differences in the abundance of the major phyla (i.e., Bacteriodetes, Firmicutes, Actinobacteria, and Proteobacteria) in Gucy2 $\mathrm{c}^{+/+}$ and Gucy $2 c^{-1-}$ mice (Fig. 6a). However, we observed a significant decrease in the abundance of Lactobacillus in Gucy $2 c^{-1-}$ mice, as has been reported earlier (16). We observed this decrease even following cohousing of Gucy $2 c^{-/-}$mice with wild-type mice (Fig. 6). Different species and isolates of Lactobacillus have been shown to exert antagonistic activity on Salmonella invasion and colonization (25-28). For example, Lactobacillus acidophilus inhibits adhesion, invasion, and dissemination of attenuated $S$. Typhimurium in BALB/C mice (25). In vitro studies in human intestinal Caco-2 cells revealed that Lactobacillus acidophilus attenuates Salmonella-induced intestinal inflammation via the transforming growth factor $\beta / M I R 21$ signaling pathway (26). The lower abundance of specific Lactobacillus spp. might inherently predispose Gucy $2 c^{-/-}$mice to Salmonella infection and contribute to the higher degree of translocation and epithelial damage in the ileum.

Microbiota dysbiosis has been reported in mice null for genes involved in fluid-ion homeostasis of the gut $(51,52)$. It is possible that GC-C enhances the growth and colonization of Lactobacillus spp. in the gut by providing and maintaining the luminal $\mathrm{pH}$ and/or electrolyte distribution and balance. Certain species of Lactobacillus have been shown to produce indole-3-aldehyde, which is an AhR ligand (49). Metagenomic analysis of the microbiome of Gucy $2 c^{-/-}$mice may reveal another mechanism by which reduced levels of specific lactobacilli could affect IL-22 production in an AhR-dependent manner.

In summary, we have studied the role of GC-C during S. Typhimurium infection in mice and have identified GC-C to be a crucial host factor that provides protection against gut-mediated infection by $S$. Typhimurium. Our results, summarized in Fig. 7, indicate that Salmonella infection results in the downregulation of GC-C ligands and a modest but significant downregulation of GC-C. The absence of GC-C in the gut modulates the innate immune response to Salmonella and cytokine production, possibly affecting neutrophil migration and/or stem cell proliferation in the distal ileum. We speculate, therefore, that administration of GC-C ligand analogs may alleviate Salmonella-mediated symptoms and pathology. Linaclotide is an FDAapproved oral GC-C ligand and is used in the treatment of constipation and chronic idiopathic constipation. This drug is effective against visceral pain associated with constipation-predominant inflammatory bowel syndrome (C-IBS) (53). Therefore, paradoxically, a target for a bacterial toxin that causes diarrhea may act as a therapeutic target for the treatment and alleviation of Salmonella-mediated intestinal symptoms and pathology. 


\section{MATERIALS AND METHODS}

Bacterial cultures. The S. Typhimurium NCTC 12023 strain was used for mouse infections. A single isolated colony of S. Typhimurium grown on a Salmonella-Shigella (SS) agar plate was used to culture the preinoculum. The overnight preinoculum was used at $0.2 \%$ in $50 \mathrm{ml}$ of Luria broth and cultured for $3 \mathrm{~h}$ at $37^{\circ} \mathrm{C}$ and $160 \mathrm{rpm}$ to obtain a log-phase culture. The bacterial culture was washed and resuspended in sterile phosphate-buffered saline (PBS) and used for infection (21).

Mice. Gucy $2 c^{-/-}$mice obtained from The Jackson Laboratory were backcrossed with C57BL/6 mice for more than 10 generations with multiple founder wild-type mice. Gucy $2 c^{+/+}$and Gucy $2 c^{-1-}$ mice were bred in the same vivarium as described previously (15), housed in a clean-air facility in multiple cages, and separated on the basis of sex and strain. The temperature was maintained at $22 \pm 2{ }^{\circ} \mathrm{C}$, the humidity was maintained at $55 \% \pm 10 \%$, and the mice were maintained on a 12-h light/12-h dark cycle. Mice had access to laboratory chow and water ad libitum. Chow was procured from Rayans Biotech, Hyderabad, India, and contained $\sim 24 \%$ protein, $6 \%$ oil, and 3\% dietary fiber. Mice of either sex aged 6 to 8 weeks and weighing 18 to $30 \mathrm{~g}$ were used for the experiments and following infection were housed in multiple cages to rule out cage-dependent effects.

In some experiments, Gucy2 $\mathrm{c}^{-1-}$ mice were cohoused at the time of weaning with adult wild-type mice for 4 weeks in multiple cages. Feces were collected from the cohoused Gucy $2 c^{-1-}$ mice, and the mice were then placed in a cage along with the wild-type mice to be used for infection. Three days later, the mice were used for infection.

Ethics statement. The experiments were performed in agreement with the Control and Supervision Rules, 1998 of Ministry of Environment and Forest Act (Government of India), and the Institutional Animal Ethics Committee of the Indian Institute of Science (IISc). Gucy $2 \mathrm{c}^{+/+}$and Gucy $2 \mathrm{c}^{-/-}$mice were bred and maintained at the Central Animal Facility of IISc (registration number 48/1999/CPCSEA, dated 1 March 1999). The experimental protocols were approved by the Committee for Purpose and Control and Supervision of Experiments on Animals (CPCSEA; permit number CAF/Ethics/216/2011). The details of the national guidelines can be found at http://envfor.nic.in/division/committee-purpose-control-and -supervision-experiments-animals-cpcsea (21).

Mouse infection. The mice were infected with S. Typhimurium either orally or intraperitoneally, and survival was monitored. For infections via the intraperitoneal route, $\sim 750$ bacteria/mouse were administered, while for oral infection, $\sim 10^{8}$ bacteria/mouse were used. The bacterial culture was resuspended in PBS, and $0.5 \mathrm{ml}$ was administered either by the intraperitoneal route or by oral gavage.

Fresh fecal samples were collected following infection, weighed, and homogenized in PBS, and the appropriate dilutions were plated on SS agar plates. For quantification of the CFU burden in organs, the mice were sacrificed at the time points indicated above and in the appropriate figures and the organs were harvested, weighed, and homogenized in PBS. Appropriate dilutions were plated on SS agar plates (20).

Serum cytokines and cortisol estimation. Serum TNF- $\alpha, \mathrm{IL}-6$, and IFN- $\gamma$ were quantified using enzyme-linked immunosorbent assay (ELISA) kits (eBioscience, USA), while serum cortisol amounts were measured using an AccuBind ELISA kit (Monobind Inc., USA) according to the manufacturer's instructions (21).

Flow cytometric analysis of thymocytes. On the days indicated above and in the appropriate figures, uninfected and infected mice were sacrificed, and the thymi were dissected and washed in PBS. The organs were disrupted with a pair of forceps, the cell suspensions were passed through a fine wire mesh to obtain a single-cell suspension, and the viability of the cells was estimated by trypan blue exclusion assay using a hemocytometer. Thymocytes were stained for cell surface expression of CD4 and CD8 to estimate the major cell subpopulations. Anti-mouse CD4-allophycocyanin (catalog number 17-0041-83) and anti-mouse CD8-phycoerythrin (catalog number 12-0081-85) were purchased from eBioscience. Cells were incubated with fluorochrome-conjugated antibodies at $4^{\circ} \mathrm{C}$ for $45 \mathrm{~min}$. Subsequently, the cells were washed twice with PBS and fixed in $0.5 \%$ paraformaldehyde. The cells were acquired on a FACSVerse flow cytometer (BD Bioscience, USA). Baseline instrument application and compensation settings were set using unstained and singly stained samples, respectively. Single events were gated on the basis of the forward scatter area versus the forward scatter height, while live events were gated on the basis of the forward scatter area versus the side scatter area. These selections were considered to exclusively analyze single live events. CD4-versus-CD8 density plots were constructed for thymocytes, and the major cell populations were quantified. WinMDI software and FlowJo (version 9.8.5) software were used to plot and analyze the results (21).

Histological analysis. Histological analysis was performed on ileal sections, which were fixed in $4 \%$ paraformaldehyde in PBS ( $\mathrm{pH}$ 6.9), and periodic acid-Schiff (PAS) staining was performed (48). Briefly, following fixation, sections were dehydrated by serial immersion in increasing concentrations of ethanol and finally in paraffin. The tissues were embedded in paraffin, and 4- $\mu \mathrm{m}$ sections were obtained using a microtome (Leica Biosystems, Germany). The sections were dewaxed and rehydrated by serial immersion in decreasing concentrations of ethanol. Sections were stained with PAS (Avinash Chemicals, Bangalore, India) following the manufacturer's instructions. The nuclei were subsequently stained with hematoxylin (Sigma-Aldrich, USA). Sections were then dehydrated and mounted. The sections were observed using an Olympus XI81 microscope (Olympus Corporation, Tokyo, Japan).

RNA isolation and quantitative real-time PCR analysis. A portion of the distal ileum was isolated and stored in the TRI Reagent (RNAiso Plus, TaKaRa). The RNA was isolated using a Qiagen RNeasy kit, according to the manufacturer's protocol, and $4 \mu \mathrm{g}$ of RNA was reverse transcribed to cDNA using RevertAid reverse transcriptase (Thermo Scientific, USA). Real-time PCR was performed using SYBR Premix Ex Taq (Tli RNase H Plus) on a CFX96 Touch real-time PCR detection system (Bio-Rad, USA). Three 
housekeeping genes, those for glyceraldehyde 3-phosphate dehydrogenase (Gapdh), the TATA box binding protein $(T b p)$, and $\beta$-actin $(A c t b)$, were used as internal normalization controls. Since all three genes showed equivalent results, Gapdh was used for subsequent normalization of the real-time PCR data. The sequences of the primers used for quantitative real-time PCR were obtained from those validated at the PrimerBank database and are available on request (54-56).

Quantitative real-time PCR amplification of 16S rRNA sequences of fecal microbiota. Bacterial DNA was isolated from fecal pellets using a QIAamp DNA stool minikit according to the manufacturer's instructions. The abundance of total bacteria and the specific intestinal bacterial phylum, class, and species were quantified by real-time PCR analysis with SYBR Premix Ex Taq (Tli RNase H Plus) on a StepOnePlus real-time PCR machine (Applied Biosystems, USA) using the $16 \mathrm{~S}$ rRNA-specific primers published earlier $(57,58)$. The efficiency of each primer was estimated (data not shown) and was found to be $>90 \%$. Relative bacterial abundance was determined using the $\Delta \Delta C_{T}$ threshold cycle $\left(C_{T}\right)$ method by employing universal primers specific for $16 \mathrm{~S}$ rRNA genes for normalization (59). The mean of the $\Delta \Delta C_{T}$ values obtained for each phylum seen in wild-type mice was calculated, and this value was used to express the fold change in individual $\Delta \Delta C_{T}$ values for wild-type and Gucy $2 C^{-/-}$mice, to obtain the data shown in Fig. 6.

Statistical analysis. All data were analyzed using GraphPad Prism (version 7) software. The pooled results from independent experiments are depicted as the mean \pm standard deviation (SD). All data were tested for a normality distribution by the Shapiro-Wilk normality test and found to be normally distributed. The statistical significance of the difference among groups of mice was determined using two-way analysis of variance (ANOVA) with multiple comparisons and the false discovery rate, obtained by the two-stage linear step-up procedure of Benjamini, Krieger, and Yekutieli. The Mann-Whitney $U$ test was used for comparing the abundance of microbiota in fecal samples. The statistical significance of the difference between the mouse survival curves was obtained by the Gehan-Breslow-Wilcoxon test. The $P$ values are denoted in the figure legends.

\section{ACKNOWLEDGMENTS}

We acknowledge the provision of the facilities for housing mice by the Central Animal Facility at the Indian Institute of Science. S.S.V. thanks Gad Frankel and Avinash R. Shenoy in the Centre for Molecular Bacteriology and Infection at Imperial College, London, for useful discussions.

Financial support from the Department of Biotechnology (DBT), Government of India (to S.S.V.), is acknowledged, as is the support provided to the Division of Biological Sciences in the form of a grant-in-aid by DBT. S.S.V. is a J. C. Bose national fellow, and support from the Department of Science and Technology, Government of India, is acknowledged. S.S.V. is a recipient, along with Gad Frankel from Imperial College London, of a Royal Society International Collaboration Award for Research Professors.

\section{REFERENCES}

1. Santos RL, Raffatellu M, Bevins CL, Adams LG, Tukel C, Tsolis RM, Baumler AJ. 2009. Life in the inflamed intestine, Salmonella style. Trends Microbiol 17:498-506. https://doi.org/10.1016/j.tim.2009.08.008.

2. Hapfelmeier S, Hardt WD. 2005. A mouse model for S. typhimuriuminduced enterocolitis. Trends Microbiol 13:497-503. https://doi.org/10 .1016/j.tim.2005.08.008.

3. Stecher B, Paesold G, Barthel M, Kremer M, Jantsch J, Stallmach T, Heikenwalder M, Hardt WD. 2006. Chronic Salmonella enterica serovar Typhimurium-induced colitis and cholangitis in streptomycin-pretreated Nramp1+/+ mice. Infect Immun 74:5047-5057. https://doi.org/10.1128/ IAl.00072-06.

4. Bao S, Beagley KW, France MP, Shen J, Husband AJ. 2000. Interferongamma plays a critical role in intestinal immunity against Salmonella typhimurium infection. Immunology 99:464-472. https://doi.org/10 .1046/j.1365-2567.2000.00955.x.

5. Arnold JW, Niesel DW, Annable CR, Hess CB, Asuncion M, Cho YJ, Peterson JW, Klimpel GR. 1993. Tumor necrosis factor-alpha mediates the early pathology in Salmonella infection of the gastrointestinal tract. Microb Pathog 14:217-227. https://doi.org/10.1006/mpat.1993.1021.

6. Arnold JW, Klimpel GR, Niesel DW. 1993. Tumor necrosis factor (TNF alpha) regulates intestinal mucus production during salmonellosis. Cell Immunol 151:336-344. https://doi.org/10.1006/cimm.1993.1243.

7. Sadik CD, Kim ND, Luster AD. 2011. Neutrophils cascading their way to inflammation. Trends Immunol 32:452-460. https://doi.org/10.1016/j.it .2011.06.008.

8. Zhou D, Galan J. 2001. Salmonella entry into host cells: the work in concert of type III secreted effector proteins. Microbes Infect 3:1293-1298. https://doi.org/10.1016/S1286-4579(01)01489-7.
9. Currie MG, Fok KF, Kato J, Moore RJ, Hamra FK, Duffin KL, Smith CE. 1992 Guanylin: an endogenous activator of intestinal guanylate cyclase. Proc Natl Acad Sci U S A 89:947-951

10. Hamra FK, Forte LR, Eber SL, Pidhorodeckyj NV, Krause WJ, Freeman RH, Chin DT, Tompkins JA, Fok KF, Smith CE, Duffin KL, Siegel N, Currie MG. 1993. Uroguanylin: structure and activity of a second endogenous peptide that stimulates intestinal guanylate cyclase. Proc Natl Acad Sci U S A 90:10464-10468.

11. Basu N, Arshad N, Visweswariah SS. 2010. Receptor guanylyl cyclase C (GC-C): regulation and signal transduction. Mol Cell Biochem 334:67-80. https://doi.org/10.1007/s11010-009-0324-x.

12. Schulz S, Green CK, Yuen PS, Garbers DL. 1990. Guanylyl cyclase is a heat-stable enterotoxin receptor. Cell 63:941-948. https://doi.org/10 .1016/0092-8674(90)90497-3.

13. Schulz S, Lopez MJ, Kuhn M, Garbers DL. 1997. Disruption of the guanylyl cyclase-C gene leads to a paradoxical phenotype of viable but heatstable enterotoxin-resistant mice. J Clin Invest 100:1590-1595. https:// doi.org/10.1172/JCl119683.

14. Lin JE, Snook AE, Li P, Stoecker BA, Kim GW, Magee MS, Garcia AV, Valentino MA, Hyslop T, Schulz S, Waldman SA. 2012. GUCY2C opposes systemic genotoxic tumorigenesis by regulating AKT-dependent intestinal barrier integrity. PLoS One 7:e31686. https://doi.org/10.1371/ journal.pone.0031686.

15. Basu N, Saha S, Khan I, Ramachandra SG, Visweswariah SS. 2014. Intestinal cell proliferation and senescence are regulated by receptor guanylyl cyclase C and p21. J Biol Chem 289:581-593. https://doi.org/10.1074/ jbc.M113.511311.

16. Mann EA, Harmel-Laws E, Cohen MB, Steinbrecher KA. 2013. Guanylate 
cyclase $C$ limits systemic dissemination of a murine enteric pathogen. BMC Gastroenterol 13:135. https://doi.org/10.1186/1471-230X-13-135.

17. Barthel M, Hapfelmeier S, Quintanilla-Martinez L, Kremer M, Rohde $M$, Hogardt M, Pfeffer K, Russmann H, Hardt WD. 2003. Pretreatment of mice with streptomycin provides a Salmonella enterica serovar Typhimurium colitis model that allows analysis of both pathogen and host. Infect Immun 71:2839-2858. https://doi.org/10.1128/IAI.71.5.2839-2858 .2003 .

18. Sekirov I, Tam NM, Jogova M, Robertson ML, Li Y, Lupp C, Finlay BB. 2008. Antibiotic-induced perturbations of the intestinal microbiota alter host susceptibility to enteric infection. Infect Immun 76:4726-4736. https:// doi.org/10.1128/IAI.00319-08.

19. Ren Z, Gay R, Thomas A, Pae M, Wu D, Logsdon L, Mecsas J, Meydani SN. 2009. Effect of age on susceptibility to Salmonella Typhimurium infection in C57BL/6 mice. J Med Microbiol 58:1559-1567. https://doi.org/10 .1099/jmm.0.013250-0.

20. Deobagkar-Lele M, Chacko SK, Victor ES, Kadthur JC, Nandi D. 2013. Interferon-gamma- and glucocorticoid-mediated pathways synergize to enhance death of $\mathrm{CD} 4(+) \mathrm{CD} 8(+)$ thymocytes during Salmonella enterica serovar Typhimurium infection. Immunology 138:307-321. https:// doi.org/10.1111/imm.12047.

21. Majumdar S, Deobagkar-Lele M, Adiga V, Raghavan A, Wadhwa N, Ahmed SM, Rananaware SR, Chakraborty S, Joy O, Nandi D. 2017. Differential susceptibility and maturation of thymocyte subsets during Salmonella Typhimurium infection: insights on the roles of glucocorticoids and interferon-gamma. Sci Rep 7:40793. https://doi.org/10.1038/ srep40793.

22. Ikpa PT, Sleddens HF, Steinbrecher KA, Peppelenbosch MP, de Jonge HR, Smits R, Bijvelds MJ. 2016. Guanylin and uroguanylin are produced by mouse intestinal epithelial cells of columnar and secretory lineage. Histochem Cell Biol 146:445-455. https://doi.org/10.1007/s00418-016 -1453-4.

23. Arshad N, Visweswariah SS. 2012. The multiple and enigmatic roles of guanylyl cyclase $C$ in intestinal homeostasis. FEBS Lett 586:2835-2840. https://doi.org/10.1016/j.febslet.2012.07.028.

24. LaRock DL, Chaudhary A, Miller SI. 2015. Salmonellae interactions with host processes. Nat Rev Microbiol 13:191-205. https://doi.org/10.1038/ nrmicro3420.

25. Nakazato G, Paganelli FL, Lago JC, Aoki FH, Mobilon C, Brocchi M, Stehling EG, Silveira WD. 2011. Lactobacillus acidophilus decreases Salmonella Typhimurium invasion in vivo. J Food Saf 31:284-289. https:// doi.org/10.1111/j.1745-4565.2011.00299.x.

26. Huang IF, Lin IC, Liu PF, Cheng MF, Liu YC, Hsieh YD, Chen JJ, Chen CL, Chang HW, Shu CW. 2015. Lactobacillus acidophilus attenuates Salmonella-induced intestinal inflammation via TGF-beta signaling. BMC Microbiol 15:203. https://doi.org/10.1186/s12866-015-0546-x.

27. Abdel-Daim A, Hassouna N, Hafez M, Ashor MS, Aboulwafa MM. 2013. Antagonistic activity of Lactobacillus isolates against Salmonella typhi in vitro. Biomed Res Int 2013:680605. https://doi.org/10.1155/2013/680605.

28. Coconnier MH, Lievin V, Lorrot M, Servin AL. 2000. Antagonistic activity of Lactobacillus acidophilus LB against intracellular Salmonella enterica serovar Typhimurium infecting human enterocyte-like Caco-2/TC-7 cells. Appl Environ Microbiol 66:1152-1157. https://doi.org/10.1128/AEM.66.3 .1152-1157.2000.

29. Nicolaides NC, Kyratzi E, Lamprokostopoulou A, Chrousos GP, Charmandari E. 2015. Stress, the stress system and the role of glucocorticoids. Neuroimmunomodulation 22:6-19. https://doi.org/10.1159/000362736.

30. Tannock GW, Blumershine RV, Savage DC. 1975. Association of Salmonella typhimurium with, and its invasion of, the ileal mucosa in mice. Infect Immun 11:365-370.

31. Stecher B, Macpherson AJ, Hapfelmeier S, Kremer M, Stallmach T, Hardt WD. 2005. Comparison of Salmonella enterica serovar Typhimurium colitis in germfree mice and mice pretreated with streptomycin. Infect Immun 73:3228-3241. https://doi.org/10.1128/IAI.73.6.3228-3241.2005.

32. Caprilli R. 2008. Why does Crohn's disease usually occur in terminal ileum? J Crohn's Colitis 2:352-356. https://doi.org/10.1016/j.crohns.2008 .06 .001 .

33. Cominelli F, Arseneau KO, Rodriguez-Palacios A, Pizarro TT. 2017. Uncovering pathogenic mechanisms of inflammatory bowel disease using mouse models of Crohn's disease-like ileitis: what is the right model? Cell Mol Gastroenterol Hepatol 4:19-32. https://doi.org/10.1016/j.jcmgh .2017.02.010.

34. He P, Yun CC. 2010. Mechanisms of the regulation of the intestinal
$\mathrm{Na}^{+} / \mathrm{H}^{+}$exchanger NHE3. J Biomed Biotechnol 2010:238080. https://doi .org/10.1155/2010/238080.

35. Lan D, Niu J, Miao J, Dong X, Wang H, Yang G, Wang K, Miao Y. 2016. Expression of guanylate cyclase- $C$, guanylin, and uroguanylin is downregulated proportionally to the ulcerative colitis disease activity index. Sci Rep 6:25034. https://doi.org/10.1038/srep25034.

36. Brenna $\varnothing$, Bruland T, Furnes MW, Granlund AVB, Drozdov I, Emgård J, Brønstad G, Kidd M, Sandvik AK, Gustafsson BI. 2015. The guanylate cyclase-C signaling pathway is down-regulated in inflammatory bowel disease. Scand J Gastroenterol 50:1241-1252. https://doi.org/10.3109/ 00365521.2015.1038849.

37. Pattison AM, Merlino DJ, Blomain ES, Waldman SA. 2016. Guanylyl cyclase $C$ signaling axis and colon cancer prevention. World J Gastroenterol 22:8070-8077. https://doi.org/10.3748/wjg.v22.i36.8070.

38. Nakano Y, Onozuka K, Terada Y, Shinomiya H, Nakano M. 1990. Protective effect of recombinant tumor necrosis factor-alpha in murine salmonellosis. J Immunol 144:1935-1941.

39. Tracey KJ, Beutler B, Lowry SF, Merryweather J, Wolpe S, Milsark IW, Hariri RJ, Fahey TJ, III, Zentella A, Albert JD, Shires G, Cerami A. 1986. Shock and tissue injury induced by recombinant human cachectin. Science 234:470-474. https://doi.org/10.1126/science.3764421.

40. Beutler B, Grau GE. 1993. Tumor necrosis factor in the pathogenesis of infectious diseases. Crit Care Med 21:S423-S435. https://doi.org/10.1097/ 00003246-199310001-00002.

41. Zheng Y, Danilenko DM, Valdez P, Kasman I, Eastham-Anderson J, Wu J, Ouyang W. 2007. Interleukin-22, a T(H)17 cytokine, mediates IL-23induced dermal inflammation and acanthosis. Nature 445:648-651. https://doi.org/10.1038/nature05505.

42. Powell N, Lo JW, Biancheri P, Vossenkamper A, Pantazi E, Walker AW, Stolarczyk E, Ammoscato F, Goldberg R, Scott P, Canavan JB, Perucha E, Garrido-Mesa N, Irving PM, Sanderson JD, Hayee B, Howard JK, Parkhill J, MacDonald T, Lord GM. 2015. Interleukin 6 increases production of cytokines by colonic innate lymphoid cells in mice and patients with chronic intestinal inflammation. Gastroenterology 149:456-467.e15. https://doi.org/10.1053/j.gastro.2015.04.017.

43. Vaishnava S, Yamamoto M, Severson KM, Ruhn KA, Yu X, Koren O, Ley R, Wakeland EK, Hooper LV. 2011. The antibacterial lectin Reglllgamma promotes the spatial segregation of microbiota and host in the intestine. Science 334:255-258. https://doi.org/10.1126/science.1209791.

44. Behnsen J, Jellbauer S, Wong CP, Edwards RA, George MD, Ouyang W, Raffatellu M. 2014. The cytokine IL-22 promotes pathogen colonization by suppressing related commensal bacteria. Immunity 40:262-273. https://doi.org/10.1016/j.immuni.2014.01.003.

45. van Ampting MTJ, Loonen LMP, Schonewille AJ, Konings I, Vink C, lovanna J, Chamaillard M, Dekker J, van der Meer R, Wells JM. 2012. Intestinally secreted C-type lectin Reg3b attenuates salmonellosis but not listeriosis in mice. Infect Immun 80:1115-1120. https://doi.org/10 .1128/IAI.06165-11.

46. Loonen LM, Stolte EH, Jaklofsky MT, Meijerink M, Dekker J, van Baarlen P, Wells JM. 2014. REG3gamma-deficient mice have altered mucus distribution and increased mucosal inflammatory responses to the microbiota and enteric pathogens in the ileum. Mucosal Immunol 7:939-947. https://doi.org/10.1038/mi.2013.109.

47. Lindemans $C A$, Calafiore $M$, Mertelsmann AM, O'Connor MH, Dudakov $J A$, Jenq RR, Velardi E, Young LF, Smith OM, Lawrence G, Ivanov JA, Fu YY, Takashima S, Hua G, Martin ML, O'Rourke KP, Lo YH, Mokry M, Romera-Hernandez M, Cupedo T, Dow LE, Nieuwenhuis EE, Shroyer NF, Liu C, Kolesnick R, Van Den Brink MRM, Hanash AM. 2015. Interleukin-22 promotes intestinal-stem-cell-mediated epithelial regeneration. Nature 528:560-564. https://doi.org/10.1038/nature16460.

48. Murray IA, Perdew GH. 2017. Ligand activation of the Ah receptor contributes to gastrointestinal homeostasis. Curr Opin Toxicol 2:15-23. https://doi.org/10.1016/j.cotox.2017.01.003.

49. Zelante T, lannitti RG, Cunha C, Deluca A, Giovannini G, Pieraccini G, Zecchi R, D'Angelo C, Massi-Benedetti C, Fallarino F, Carvalho A, Puccetti $P$, Romani L. 2013. Tryptophan catabolites from microbiota engage aryl hydrocarbon receptor and balance mucosal reactivity via interleukin-22. Immunity 39:372-385. https://doi.org/10.1016/j.immuni.2013.08.003.

50. Bäumler AJ, Sperandio V. 2016. Interactions between the microbiota and pathogenic bacteria in the gut. Nature 535:85-93. https://doi.org/10 .1038 /nature18849.

51. Larmonier CB, Laubitz D, Hill FM, Shehab KW, Lipinski L, Midura-Kiela MT, McFadden RM, Ramalingam R, Hassan KA, Golebiewski M, Besselsen DG, Ghishan FK, Kiela PR. 2013. Reduced colonic microbial diversity is asso- 
ciated with colitis in NHE3-deficient mice. Am J Physiol Gastrointest Liver Physiol 305:G667-G677. https://doi.org/10.1152/ajpgi.00189.2013.

52. Norkina O, Burnett TG, De Lisle RC. 2004. Bacterial overgrowth in the cystic fibrosis transmembrane conductance regulator null mouse small intestine. Infect Immun 72:6040-6049. https://doi.org/10.1128/IAl.72.10 .6040-6049.2004.

53. Castro J, Harrington AM, Hughes PA, Martin CM, Ge $P$, Shea $C M$, Jin $H_{\text {, }}$ Jacobson S, Hannig G, Mann E, Cohen MB, MacDougall JE, Lavins BJ, Kurtz CB, Silos-Santiago I, Johnston JM, Currie MG, Blackshaw LA, Brierley SM. 2013. Linaclotide inhibits colonic nociceptors and relieves abdominal pain via guanylate cyclase- $\mathrm{C}$ and extracellular cyclic guanosine 3',5'-monophosphate. Gastroenterology 145:1311-1334. https://doi.org/10.1053/j.gastro.2013.08.017.

54. Wang X, Seed B. 2003. A PCR primer bank for quantitative gene expression analysis. Nucleic Acids Res 31:e154. https://doi.org/10.1093/nar/gng154.

55. Spandidos A, Wang X, Wang H, Dragnev S, Thurber T, Seed B. 2008. A comprehensive collection of experimentally validated primers for polymerase chain reaction quantitation of murine transcript abundance. BMC Genomics 9:633. https://doi.org/10.1186/1471-2164-9-633.
56. Spandidos A, Wang X, Wang H, Seed B. 2010. PrimerBank: a resource of human and mouse PCR primer pairs for gene expression detection and quantification. Nucleic Acids Res 38:D792-D799. https://doi.org/10.1093/ nar/gkp1005.

57. Yang Y-W, Chen M-K, Yang B-Y, Huang X-J, Zhang X-R, He L-Q, Zhang J, Hua Z-C. 2015. Use of $16 \mathrm{~S}$ rRNA gene-targeted group-specific primers for real-time $P C R$ analysis of predominant bacteria in mouse feces. Appl Environ Microbiol 81:6749-6756. https://doi.org/10.1128/ AEM.01906-15.

58. Clifford RJ, Milillo M, Prestwood J, Quintero R, Zurawski DV, Kwak YI, Waterman PE, Lesho EP, Mc Gann P. 2012. Detection of bacterial 16S rRNA and identification of four clinically important bacteria by realtime PCR. PLoS One 7:e48558. https://doi.org/10.1371/journal.pone .0048558 .

59. Feng Y, Gong J, Yu H, Jin Y, Zhu J, Han Y. 2010. Identification of changes in the composition of ileal bacterial microbiota of broiler chickens infected with Clostridium perfringens. Vet Microbiol 140:116-121. https://doi.org/10 .1016/j.vetmic.2009.07.001. 